Research article

\title{
Practice and professional development plans (PPDPs): results of a feasibility study Glyn Elwyn* ${ }^{* 1}$, Sandra Carlisle ${ }^{2}$, Paul Hocking ${ }^{3}$ and Simon Smail ${ }^{2}$
}

Address: ${ }^{1}$ Department of General Practice University of Wales College of Medicine Canolfan lechyd Llanedeym Health Centre Cardiff CF23 9PN, UK, ${ }^{2}$ Department of Postgraduate Education for General Practice University of Wales College of Medicine Heath Park Cardiff CF14 4XN, UK and ${ }^{3}$ Primary Care Development Research Group NHS Staff College Wales Hensol Castle Pontyclun Mid Glamorgan CF72 8YS, UK

E-mail: Glyn Elwyn* - Elwyng@cf.ac.uk; Sandra Carlisle - scarlisle@srv1.med.ed.ac.uk; Paul Hocking - phocking@StaffCollegeWales.org.uk; Simon Smail - smail@cardiff.ac.uk

*Corresponding author

Published: 27 March 200I

BMC Family Practice 200I, 2:I
Received: I4 February 200 I

Accepted: 27 March 2001

This article is available from: http://www.biomedcentral.com/I47/-2296/2/I

(c) 200 I Elwyn et al, licensee BioMed Central Ltd.

\begin{abstract}
Background: Dissatisfaction with uniprofessional education structures as a means of improving the quality of healthcare has led to proposals to develop ways of integrating professional learning and organisational development.
\end{abstract}

Aims: Test the feasibility of introducing practice and professional development plans using a centrally sponsored project in Wales.

Design: Qualitative observational study.

Study sample: All 54I practices in Wales were alerted to the project and invited to apply. A selection process was suggested to Health Authorities but not always efficiently conducted: 23 practices were selected and 18 participated in the process.

Method: Central funding was made available to health authorities. The project framework was designed by an educational department and conceptualised as the development of personal portfolios linked to one key organisation change in each practice, facilitated by external consultants who would typically hold workshops or other events. An independent researcher using nonparticipant observation techniques at workshops and practices undertook documentary analysis and fieldwork in four health authorities.

Results: Difficulties were encountered with the process of implementing the project: marketing and practice selection inconsistencies delayed the work and it was difficult to recruit practices into the project. The lack of experienced individuals to do the work and practitioner suspicion about perceived 'management' agendas were significant problems. After initial hesitancies most practices appreciated the value of developing wider ownership and commitment to proposed practice changes. Organisations found it difficult to support individual completion of the personal portfolio component of the plans. The ability to develop systems for clinical services was dependent on having already established a culture of effective teamwork in the organisation.

Conclusions: This work supports the view that organisational development has considerable potential for bringing about effective change, and individual contributions could form a valuable component of personal portfolios. We believe that the existing structures in education and management in the health service are not yet able to support these processes. Evidence from the fields of risk management and quality improvement all point to the need to develop effective organisational systems and the results of this feasibility study indicate that alternative models of sustaining organisational development need careful evaluation. 


\section{Introduction}

The drive to improve the quality of patient care puts 'lifelong learning' and 'continuing professional development' centre stage in the UK, but, as in other countries, there is an increasing realisation that 'real improvement comes from changing systems, not changing within systems' [1]. This attention on systems puts much more of an emphasis on organisational development [1-5]. In addition, the recognised limitations of didactic and uniprofessional continuing education [6-8] led to the Chief Medical Officer's review of professional development in primary care. This report recommended that practice and professional development plans should replace existing arrangements as a way of shifting the focus onto systemic interventions [9-11]. Although it is appreciated that high quality health care depends on professional collaboration, very little research has been done on how best to develop effective care processes and implement new systems [12].

Practice and professional development plans (PPDPs) have therefore emerged as a widely anticipated replacement in general practice to attendance-based educational systems, incentivised in the UK by the postgraduate educational allowance (PGEA). PPDPs are envisaged to be part of the emphasis placed on learning organisations [13] with the added element of encouraging participants to maintain personal portfolios - which are also likely to be the basis of revalidation [14]. They seem to have been conceptualised as formative organisational plans [15] that can contribute to an individual's professional development portfolio $[16,17]$.

General practitioners are wary of PPDPs, and the potential opportunity costs involved $[15,18]$. This study was therefore set up to assess the feasibility of implementing PPDPs using the management capabilities within Health Authorities. The project was evaluated by a researcher who had no responsibility for the implementation process using qualitative observational methods.

\section{Method}

The PPDP project was planned by a postgraduate education department for general practice but managed by coordinators appointed in the five health authorities (budget holders) in Wales - as an additional task to their usual roles. Every practice was given the opportunity to apply and the selection process was designed to ensure that one practice per Local Health Group (LHG) - equivalent in Wales to Primary Care Groups (PCG) in England - be recruited into the study. The Welsh Office (1998) felt that this would enable the LHGs to gain valuable experience of the PPDP initiative. The project initiation document provided detailed information about the concept and constitution of a multiprofessional selection panel.
The timetable suggested 2 months for marketing, 1 month for selection and 10 months for completion. The health authorities were asked to identify workshop facilitators that could be contracted to support practice organisational development.

\section{Evaluation criteria and study method}

A full time independent research officer evaluated the work using, process-focused qualitative research methods that included non-participant observation, interviews and documentary analysis over a period of 15 months [19-22]. 40 workshops involving 16 practices were observed in 4 health authorities, and participants interviewed. The project initiation document [21] incorporated evaluation criteria that informed the observation and interview schedules. Practices were evaluated using both process and outcome criteria [21], which included the appointment and use of experienced facilitators, clearly defined development goals based on a needs assessment exercise, involvement of an appropriate group of professionals for the chosen task, patient awareness and contribution to the change processes and the establishment of a planned organisational change in the practice. Field notes and other documents (practice applications; workshop reports; final plans describing practice-specific outcomes) provided a substantial basis for thematic analysis using a template approach developed during data collection [23]. A final version of this paper was circulated to all practices, facilitators and coordinators to ensure factual and presentational accuracy, and agreement achieved. The participating practices were contacted after the completion date to verify the documented outcomes and to explore the sustained impact of the completed PPDP process.

\section{Results \\ Project Marketing}

There was significant variation in the timing and enthusiasm of the marketing exercise performed by the health authorities. In one area, financial resources were advertised prominently but left unmentioned in others. In three authorities, practices were not provided with the project initiation document and had to make applications on the basis of sparse information. In Gwent, initial applicants were asked to re-submit and comply with additional locally imposed steps.

The Welsh Office stipulation that one practice per LHG should be selected led to significant delays. For example, of the 6 applications in Bro Taf, 5 came from one LHG (Cardiff) and one from Merthyr, leaving two LHGs without applicants. Similar gaps occurred in other areas (except for Dyfed Powys), and some coordinators eventually felt compelled to cajole practices (see Table 1). Adherence to the suggested selection process was variable and 
inefficiently conducted in some, but not all, areas. The average time for practice selection was 6 months, with the range of 3 to 11 months. The fact that less than 10\% of practices in Wales showed any interest in the PPDP process was investigated and found to be partly attributable to suspicions about the health authorities' agenda as organisers of PPDPs and the climate of change fatigue in 1998, as many extracted themselves from fundholding arrangements.

\section{PPDP facilitators}

The criteria for PPDP facilitators were: capacity to provide a series of interactive workshops over a period of 9 months, ability to support organisational development and experience of teaching others how to use portfolios for professional development. These skills were scarce (and time even scarcer) within health authorities. Other potential candidates, such as general practice tutors, lacked time and experience of facilitating organisational development. We were not able to locate facilitators who had prior experience of leading portfolio learning. Contracts were eventually placed with four providers: three independent companies and one NHS management training organisation (NHS Staff College Wales).

The health authority coordinators initially arranged 'marriages' between facilitators and practices. This approach sometimes resulted in a lack of practice ownership and concerns that the facilitators were management agents. This process was revised and facilitators were asked to provide a presentation to selected practices, who were then allowed a free choice. This 'beauty parade' process increased the sense of commitment. The coordinator in Gwent allowed practices to devise their own facilitation arrangements but only highly motivated practices managed to make progress (see Table 2).

\section{Participants and process}

The 23 participating general practices included 3 practices from valley communities, 7 from cities or large towns and the remainder were from rural or market town settings. Three practices had less than 4,000 patients and 6 practices had lists above 10,000. They did not have prior experience of facilitated organisation-wide development or portfolio-based learning.

Typical PPDP workshops took place in half-day sessions, either at neutral venues or in practice meeting rooms. Initial sessions were devoted to explaining the PPDP concept and agreeing the organisation's development priorities. In subsequent sessions some practices met regularly to review progress on agreed tasks and a number undertook visits to other practices.
General practitioners shaped the project groups in differing ways and usually involved one or more of the following arrangements:

- 'core' groups: general practitioners, practice manager and practice nurse

- practice-based groups: as above plus administrative staff

- extended groups: as above plus others e.g. community nurses and health visitors, pharmacists, social workers, occupational and physiotherapists.

The task of agreeing dates for the workshop took several months and illustrated the low priority given PPDPs, compared to meeting service demands. Many doctors were uncertain about closing the practice for half a day in order to allow maximum participation, and were not convinced that time spent on organisational development was a good investment. 'Core' groups found their development objectives to be unachievable without the collaboration of others. Conversely, extended groups experienced difficulty focusing on practice development needs and tensions emerged between practice priorities and community-orientated aspirations. Some practices had predetermined proposals but most allowed goals to emerge. Development priorities focused mainly on improving operational systems and procedures as general practitioners believed these to be essential for good quality patient care. There were examples of raised expectations leading to frustration, for example, a small practice (list 2400) identified an urgent need for new premises to create space for additional roles and new colleagues but subsequently received no active support from the health authority. Workshops occasionally exposed poor professional relationships, either within the organisation or in the wider network. Plans to develop clinical services had to be shelved until these problems were resolved.

As the PPDP process developed, opinions changed. Participants appreciated the 'luxury of thinking space' provided by the workshops. It became clear that facilitated 'time out' was a useful method of designing, implementing and managing organisational change. However, the benefit for personal development was less apparent. Some general practitioners expressed concern about the possible replacement of the existing postgraduate education system. They perceived PPDPs as an inappropriate vehicle for their own professional education and viewed their inclusive nature as a 'dumbing down' procedure. In the words of one doctor, 'there's a flaw in tying personal and practice development together.' These anxieties were partly resolved as individuals realised the benefit of linking personal learning to the enhancement of organisational systems. Box 1 summarises the key lessons identified. 
Table I: Practice response to the initial invitation to apply

\begin{tabular}{llll}
\hline Health Authority & $\begin{array}{l}\text { Local Health Groups } \\
\text { represented by 'voluntary' } \\
\text { applications }\end{array}$ & $\begin{array}{l}\text { Number of 'eventual' practice } \\
\text { applications / total in HA (\%) }\end{array}$ & $\begin{array}{l}\text { Number of 'selected' } \\
\text { practices }\end{array}$ \\
\hline BroTaf & 2 out of 4 & $6 / 136(4 \%)$ & 5 \\
Gwent & 3 out of 5 & $12 / 112(11 \%)$ & 5 \\
lechyd Morgannwg & I out of 3 & $5 / 84(6 \%)$ & 3 \\
North Wales & 5 out of 6 & $15 / 124(6 \%)$ & 4 \\
Dyfed Powys & 4 out of 4 & $12 / 85(14 \%)$ & $23 / 54 \mid(4 \%)$ \\
Total & & $50 / 541(9 \%)$ & \\
\hline
\end{tabular}

Table 2: Practices, facilitators, project topics and outcomes

\begin{tabular}{|c|c|c|c|c|}
\hline $\begin{array}{l}\text { Practice Name } \\
\text { (List Size) }\end{array}$ & $\begin{array}{l}\text { Local Health } \\
\text { Group } \\
\text { (Health } \\
\text { Authority) }\end{array}$ & Facilitator & $\begin{array}{l}\text { PPDP Process } \\
\text { (number of participants per } \\
\text { workshop in brackets) }\end{array}$ & $\begin{array}{l}\text { PPDP Topic } \\
\text { Outcomes }\end{array}$ \\
\hline $\begin{array}{l}\text { North Cardiff Medical } \\
\text { Centre }(13,000)\end{array}$ & Cardiff (BroTaf) & NHS-SCW & $\begin{array}{l}5 \text { PPDP sessions: } 2 \text { extended } \\
\text { group meetings }(31,27) \text {, one visit } \\
\text { to neighbouring practice }(16) \text { and } \\
\text { two core group meetings }(8,9) \text {. }\end{array}$ & $\begin{array}{l}\text { Management of COPD and leadership develop- } \\
\text { ment. } \\
\text { Established a COPD register using British Tho- } \\
\text { racic Society protocol. } \\
\text { Improvement of the team's knowledge and skills } \\
\text { in COPD and development of clinical leadership } \\
\text { within the practice }\end{array}$ \\
\hline $\begin{array}{l}\text { Ynysangharad Surgery } \\
(2,850)\end{array}$ & $\begin{array}{l}\text { Rhondda Cynon } \\
\text { Taf (Bro Taf) }\end{array}$ & NHS-SCW & $\begin{array}{l}5 \text { PPDP sessions: } 4 \text { extended } \\
\text { group meetings }(1 \mathrm{I}, 10,10,1 \mathrm{I}) \text {, one } \\
\text { practice group meeting }(8) .\end{array}$ & $\begin{array}{l}\text { Improvement of patient waiting and time man- } \\
\text { agement. } \\
\text { Computerised appointments and patient call sys- } \\
\text { tem. Efficiency gains for patient management and } \\
\text { access. }\end{array}$ \\
\hline $\begin{array}{l}\text { Pontcae Surgery } \\
(9,430)\end{array}$ & $\begin{array}{l}\text { MerthyrTydfil } \\
\text { (BroTaf) }\end{array}$ & NHS-SCW & $\begin{array}{l}3 \text { PPDP sessions: } 3 \text { core group } \\
\text { meetings }(5,6,6) \text {. }\end{array}$ & $\begin{array}{l}\text { Planning processes discussed by partners and } \\
\text { manager. } \\
\text { Increased knowledge regarding strategic planning } \\
\text { and policy development that led to the establish- } \\
\text { ment of clinical leadership within the practice and } \\
\text { an acceptance of the need to work with differing } \\
\text { leadership styles. }\end{array}$ \\
\hline $\begin{array}{l}\text { Stanwell Road Health } \\
\text { Centre }(9,157)\end{array}$ & $\begin{array}{l}\text { Vale of Glamorgan } \\
\text { (Bro Taf) }\end{array}$ & NHS-SCW & $\begin{array}{l}\text { I PPDP session: extended group } \\
\text { meeting (22). }\end{array}$ & $\begin{array}{l}\text { Project suspended because of staff illness: no top- } \\
\text { ic chosen }\end{array}$ \\
\hline $\begin{array}{l}\text { Kings Road Surgery } \\
(5,650)\end{array}$ & $\begin{array}{l}\text { Cardiff ((Bro Taf) } \\
\text { sponsored) }\end{array}$ & NHS-SCW & $\begin{array}{l}5 \text { PPDP sessions: } 3 \text { core group } \\
\text { meetings }(7,7,7) \text {, and two visits to } \\
\text { neighbouring practices }\end{array}$ & $\begin{array}{l}\text { Clinical data management. } \\
\text { Direct entry of systematised data regarding clini- } \\
\text { cal processes within consultations. Improved } \\
\text { data management and use of audit and feedback } \\
\text { techniques to improve clinical systems. }\end{array}$ \\
\hline MeddygfaTeilo $(9,000)$ & $\begin{array}{l}\text { Carmarthenshire } \\
\text { (Dyfed Powys) }\end{array}$ & NHS-SCW & $\begin{array}{l}5 \text { PPDP sessions: } 3 \text { extended } \\
\text { group meetings }(22,16,16) \text {, one } \\
\text { core group }(9) \text { and one visit to } \\
\text { neighbouring practice. }\end{array}$ & $\begin{array}{l}\text { Enhancement of information standardisation and } \\
\text { team use of clinical database. } \\
\text { Improvement of existing high quality information } \\
\text { management systems by provision of training in } \\
\text { data quality and management for all members of } \\
\text { the practice. }\end{array}$ \\
\hline
\end{tabular}


Table 2: Practices, facilitators, project topics and outcomes

\begin{tabular}{|c|c|c|c|c|}
\hline Tan-y-Fron $(5,500)$ & $\begin{array}{l}\text { Ceredigion } \\
\text { (Dyfed Powys) }\end{array}$ & $\begin{array}{l}\text { Pi Associ- } \\
\text { ates }\end{array}$ & $\begin{array}{l}5 \text { PPDP sessions: } 4 \text { extended } \\
\text { group meetings }(12,12,13,11) \text { and } \\
\text { one core group }(3) \text { meeting. }\end{array}$ & $\begin{array}{l}\text { Improvement of a repeat prescribing system. } \\
\text { Organisation-wide protocol agreed to improve } \\
\text { the effectiveness and safety of the repeat pre- } \\
\text { scribing system, linked to the introduction of } \\
\text { weekly meetings involving practice-based and } \\
\text { Community Trust staff. }\end{array}$ \\
\hline $\begin{array}{l}\text { Winch Lane Surgery } \\
(12,800)\end{array}$ & $\begin{array}{l}\text { Pembrokeshire } \\
\text { (Dyfed Powys) }\end{array}$ & NHS-SCW & $\begin{array}{l}5 \text { PPDP sessions: } 3 \text { core group } \\
\text { meetings }(6,8,9) \text { and two sessions } \\
\text { providing personal evaluation } \\
\text { feedback to participants. }\end{array}$ & $\begin{array}{l}\text { Application for Quality Practice Award. } \\
\text { Development of specified quality systems to } \\
\text { meet the Quality Practice Award criteria and as- } \\
\text { sessment of the leadership styles and team roles } \\
\text { of selected professionals. }\end{array}$ \\
\hline $\begin{array}{l}\text { LlanfairCaereinion } \\
(4,800)\end{array}$ & $\begin{array}{l}\text { Powys (Dyfed } \\
\text { Powys) }\end{array}$ & $\begin{array}{l}\text { Pi Associ- } \\
\text { ates }\end{array}$ & $\begin{array}{l}5 \text { PPDP sessions: } 3 \text { extended } \\
\text { group meetings }(24,19,24) \text { and } \\
\text { two core group meetings }(5,5) \text {. }\end{array}$ & $\begin{array}{l}\text { Development of practice integration and com- } \\
\text { munication } \\
\text { Outcomes: Introduced regular non-medical staff } \\
\text { meetings, and Partner and Practice Manager } \\
\text { meetings. Appointing a new General Manager. }\end{array}$ \\
\hline $\begin{array}{l}\text { Morrison Road Surgery } \\
(4,600)\end{array}$ & $\begin{array}{l}\text { Neath Port Talbot } \\
\text { (Morgannwg) }\end{array}$ & $\begin{array}{l}\text { Hammond } \\
\text { Irvine }\end{array}$ & $\begin{array}{l}4 \text { PPDP sessions: } 4 \text { extended } \\
\text { group meetings }(I I, I I, I I, I I) \text {. }\end{array}$ & $\begin{array}{l}\text { Generic organisational development discussions. } \\
\text { Developed ideas for the future of the practice } \\
\text { and designed ways to improve staff management } \\
\text { and training. Efficiency gains and improved pa- } \\
\text { tient access by modifying the appointment sys- } \\
\text { tems. }\end{array}$ \\
\hline $\begin{array}{l}\text { Victoria Road Surgery } \\
(2,400)\end{array}$ & $\begin{array}{l}\text { Bridgend } \\
\text { (Morgannwg) }\end{array}$ & $\begin{array}{l}\text { Pi Associ- } \\
\text { ates }\end{array}$ & $\begin{array}{l}5 \text { PPDP sessions: } 3 \text { practice group } \\
\text { meetings }(9,9,9) \text { and two core } \\
\text { group meetings }(2,2) \text {. }\end{array}$ & $\begin{array}{l}\text { Search for solution to lack of space and high } \\
\text { workload. } \\
\text { Multiprofessional involvement in problem solv- } \\
\text { ing. Solutions identified (new premises and en- } \\
\text { hanced roles for primary care staff) but no follow } \\
\text { up support from health authority. }\end{array}$ \\
\hline $\begin{array}{l}\text { Gower Group Practice } \\
(6,255)\end{array}$ & $\begin{array}{l}\text { Swansea } \\
\text { (Morgannwg) }\end{array}$ & NHS-SCW & $\begin{array}{l}4 \text { PPDP sessions: } 4 \text { extended } \\
\text { group meetings }(14,14,12,12) \text {. }\end{array}$ & $\begin{array}{l}\text { Enhancement of information management sys- } \\
\text { tems } \\
\text { Structured data collection systems designed in } \\
\text { two clinical areas (diabetes and contraception) } \\
\text { and attention given to high-risk patients identified } \\
\text { by data audits. }\end{array}$ \\
\hline $\begin{array}{l}\text { Kinmel Avenue Surgery } \\
(13,500)\end{array}$ & Conwy (N Wales) & NHS-SCW & $\begin{array}{l}5 \text { PPDP sessions: I extended } \\
\text { group meetings ( } 23) \text {, two core } \\
\text { group }(9,7) \text { and two visits to } \\
\text { neighbouring practice. }\end{array}$ & $\begin{array}{l}\text { Practice computerisation. } \\
\text { Skills development for both clinical and ancillary } \\
\text { staff and clinicians and significant enhancement of } \\
\text { the use of information technology and communi- } \\
\text { cation within the organisation. }\end{array}$ \\
\hline $\begin{array}{l}\text { Bronyffynnon Surgery } \\
(5,200)\end{array}$ & $\begin{array}{l}\text { Denbighshire } \\
\text { (N Wales) }\end{array}$ & NHS-SCW & $\begin{array}{l}5 \text { PPDP sessions: } 3 \text { extended } \\
\text { group meetings }(16,14,14) \text {, two } \\
\text { core group consultation with ar- } \\
\text { chitect }\end{array}$ & $\begin{array}{l}\text { Improvement of practice premises. } \\
\text { A commissioned architectural audit of the cur- } \\
\text { rent and potential facilities leading } \\
\text { to a collaborative approach to the development } \\
\text { of improved use of space for clinical processes. }\end{array}$ \\
\hline $\begin{array}{l}\text { Caerffynnon Surgery } \\
(4,800)\end{array}$ & $\begin{array}{l}\text { Gwynedd } \\
\text { (N Wales) }\end{array}$ & NHS-SCW & $\begin{array}{l}5 \text { PPDP sessions: } 5 \text { extended } \\
\text { group meetings }(12,12,12,12,12) \text {. }\end{array}$ & $\begin{array}{l}\text { Care pathway for patients with terminal illness. } \\
\text { Development of a whole team understanding of } \\
\text { cancer care via case history reviews and patient } \\
\text { pathway mapping which led to planned sessions } \\
\text { of specific training and skills development. }\end{array}$ \\
\hline $\begin{array}{l}\text { Regent Street Health } \\
\text { Centre } \\
(8,150)\end{array}$ & $\begin{array}{l}\text { Wrexham } \\
\text { (N Wales) }\end{array}$ & McEwen & $\begin{array}{l}3 \text { PPDP sessions: } 3 \text { extended } \\
\text { group meetings }(13,13,13) .\end{array}$ & $\begin{array}{l}\text { Generic organisational development and proto- } \\
\text { col development. } \\
\text { Increased emphasis on developing collaborative } \\
\text { practice systems and improved communication } \\
\text { between team members to develop specific clin- } \\
\text { ical protocols. }\end{array}$ \\
\hline
\end{tabular}


Table 2: Practices, facilitators, project topics and outcomes

\begin{tabular}{|c|c|c|c|c|}
\hline $\begin{array}{l}\text { Cambria Surgery } \\
(5,200)\end{array}$ & $\begin{array}{l}\text { Ynys Mon (N } \\
\text { Wales) }\end{array}$ & McEwen & $\begin{array}{l}2 \text { PPDP sessions: } 2 \text { extended } \\
\text { group meetings }(17,15) \text {. }\end{array}$ & $\begin{array}{l}\text { Coronary heart disease and hormone replace- } \\
\text { ment clinics. }\end{array}$ \\
\hline \multirow{4}{*}{$\begin{array}{l}\text { Padeswood Road } \\
(5800)\end{array}$} & \multirow{4}{*}{$\begin{array}{l}\text { Flintshire } \\
\text { (N Wales) }\end{array}$} & \multirow{4}{*}{ McEwen } & \multirow{4}{*}{$\begin{array}{l}3 \text { PPDP sessions: } 2 \text { extended } \\
\text { group meetings }(16,16) \text { and one } \\
\text { visit to neighbouring practice. }\end{array}$} & $\begin{array}{l}\text { Patient cohorts identified in order to implement } \\
\text { a proactive system of information provisions (pa- } \\
\text { tient leaflets), triaged contact, improvement in } \\
\text { data collection and internal communication. }\end{array}$ \\
\hline & & & & $\begin{array}{l}\text { Improved practice communication and time man- } \\
\text { agement. }\end{array}$ \\
\hline & & & & $\begin{array}{l}\text { Regular practice meetings introduced and patient } \\
\text { liaison group established. }\end{array}$ \\
\hline & & & & $\begin{array}{l}\text { Staff attendance at stress management course } \\
\text { and the introduction of a counselling service to } \\
\text { selected bereaved patients. }\end{array}$ \\
\hline \multirow[t]{2}{*}{$\begin{array}{l}\text { Chippenham Surgery } \\
(11,000)\end{array}$} & \multirow[t]{2}{*}{$\begin{array}{l}\text { Monmouth } \\
\text { (Gwent) }\end{array}$} & \multirow[t]{2}{*}{ NHS-SCW } & \multirow[t]{2}{*}{$\begin{array}{l}5 \text { PPDP sessions: } 5 \text { extended } \\
\text { group meetings }(92,92,14,9,12) \text {. }\end{array}$} & $\begin{array}{l}\text { Multiprofessional collaboration to develop inter- } \\
\text { mediate care proposal. }\end{array}$ \\
\hline & & & & $\begin{array}{l}\text { Development of a multiprofessional collabora- } \\
\text { tion to establish an intermediate care proposal, } \\
\text { integrating health and social care in Gwent. }\end{array}$ \\
\hline \multirow{2}{*}{$\begin{array}{l}\text { Cwmbran Surgery } \\
(6,800)\end{array}$} & \multirow[t]{2}{*}{ Torfaen (Gwent) } & \multirow[t]{2}{*}{ Internal } & \multirow{2}{*}{$\begin{array}{l}3 \text { PPDP sessions: } 3 \text { extended } \\
\text { group meetings }(16,10,10)\end{array}$} & Care pathway for diabetes mellitus \\
\hline & & & & $\begin{array}{l}\text { Development of a multiprofessional pathway for } \\
\text { the management of chronic disease and identifi- } \\
\text { cation of training needs. }\end{array}$ \\
\hline $\begin{array}{l}\text { Glan-yr-Afon Surgery } \\
(3,564)\end{array}$ & $\begin{array}{l}\text { Blaenau Gwent } \\
\text { (Gwent) }\end{array}$ & None & PPDP process not initiated & \\
\hline $\begin{array}{l}\text { Ty Bryn Surgery } \\
(10,561)\end{array}$ & $\begin{array}{l}\text { Caerphilly } \\
\text { (Gwent) }\end{array}$ & None & PPDP process not initiated & \\
\hline $\begin{array}{l}\text { Bellevue Surgery } \\
(11,804)\end{array}$ & Newport (Gwent) & None & PPDP process not initiated & \\
\hline
\end{tabular}

key for PPDP sessions (one session approximately equivalent to 3-4 hours) E Extended General practitioners, employed staff plus others, for example, Community Nurses and Health Visitors, Community Pharmacists, Social Workers, Occupational and Physiotherapists. P Practice General practitioners and employed orattached staff based in the practice. C Core General practitioners, Practice Manager and Practice Nurse. (Pi Associates, NHS Staff College Wales (NHS-SCW), Hammond and Irvine and Ewan McEwen are the organisations that provided the PPDP facilitation skills.

\section{Discussion Principal findings}

Introducing general practices to PPDPs by using a short time-scale top-down initiative that required competitive applications for health authority controlled budgets and the imposition of external facilitation was an unwieldy method. The recruitment methods used will, in our opinion, limit responses to be from those who are already confident to tackle the suggested tasks of coordinating an application and may work against those who be starting from a lower base, thus introducing an inverse bias [24]. Health authority management had severe limitations on their capacity to take on this work, external facilitation was relatively expensive yet reflected the realities of commercial rates for this type of work. However, when practices were allowed to choose facilitators and had time to understand the aims of PPDPs, both ownership and commitment to the process increased noticeably. As practices experienced external facilitation, they welcomed the opportunity to learn as organisations and readily appreciated the potential benefits of involving a wide group of relevant professionals in the development of new systems of service delivery. Provided more effective methods of marketing and sustaining PPDPS are devised and tested, the outcomes at organisational levels demonstrate the benefit of using a systems based method of achieving change in primary care.

\section{Strengths and weaknesses of the study}

We believe that the strength of this study is its comprehensive account of the complexity involved in supporting organisational change in primary care. We are not aware of any other studies that have tracked the implementation, facilitation and outcomes of organisational development initiatives. Evaluation of the project was a continuous process from inception to completion, using multiple qualitative research methods to record, describe and analyse the convoluted social and organisational processes involved. From this contextual basis we highlight some key issues likely to confront the organisational development of general practice. We recognise that this was an uncontrolled observational study and 
Skill shortage: Supporting organisational development and making linkages to professional development (maintaining personal portfolios) requires expert facilitation skills and sustained commitment. These resources are not available in sufficient depth within the NHS or in the associated educational establishments.

Realistic timescales: Engaging general practices in a systems-wide approach to change require realistic timescales. Novel methods of working need to be explained, accepted and tested before they are adopted, especially in multiprofessional contexts.

Risky learning process: Introducing the concept of organisational learning entails accepting the risks of group processes. Unlike passive learning, active collaborative processes often expose conflicts, poor individual performance and may threaten the stability of fragile relationships.

Resources: In this feasibility study, health authorities were allocated $£ 7,500$ per practice: an acceptable sum if PPDPs help deliver higher quality services. It is not clear whether the costs of PPDPs belong to management budgets or to professional development budgets, and if so which profession?

Tension of two tasks: PPDPs set out to support both organisational change and the documentation of individual contribution to that process (via personal portfolios or their equivalent). It was not possible for one facilitator to support these two different objectives, especially given the diverse educational systems of primary care professionals.

General practice or primary care: At the core of PPDPs is the concept of organisational learning. General practitioners typically view the organisation as the practice and its associated staff. Other primary care providers however are more aware of community-orientated priorities. Future initiatives need to be clear about the remit of the development plans.

\section{Box I}

\section{Lessons from the PPDP feasibility study}

\section{Key messages}

- Multiprofessional organisations are needed to support the complexity and diversity of learning that PPDPs require, so that change is seen as anduring investment and not perceived as a series of short-term projects

- There are tensions between the organisational priorities of general practitioners, their core team and the goals of the broader 'team' in primary care

- Organisational development frameworks could facilitate continuing professional development but personal learning is only one component of system change

- General practitioners, particularly those in well developed practices, believe good quality patient care is largely dependent on improving operational systems and procedures and regard them as important development goals

\section{Box 2}


that no standardised outcome measures are available for this type of intervention [25]. We therefore assessed outcomes by assessing progress against each practice's stated aims. Further research should measure baseline organisational capacity and to be prepared to assess change over a longer timeframe.

\section{Implications}

Although it was anticipated that PPDPs would replace the postgraduate education allowance system there have been no further statutory announcements and it is not clear whether the recommendations of the Chief Medical Officer's review will be taken forward [9]. It seems likely that personal portfolios will be required for revalidation purposes but there are no plans emerging about how best to support organisational development in primary care, despite evidence of benefit and a recognised need to fulfil clinical governance requirements [26].

If PPDPs are introduced, the results of this project could guide the implementation process. The skills required to facilitate organisational development do not have a natural home in the NHS nor do they sit comfortably in the uniprofessional departments of postgraduate education for general practice. Managerial systems (health authorities and primary care health groups) are viewed with suspicion by service providers and we found no evidence that they had the necessary background or the skills to support the development of learning organisations [27]. Practices are likely to be most enthusiastic about these opportunities when they understand and agree with the aims of the exercise, feel ready to take on the challenge of addressing change using a group-based approach, have complete confidence in the facilitation process and believe outcomes to be worth the effort involved. Perhaps the introduction of accountability procedures and salaried general practitioners will focus more attention on these issues?

In summary, this work supports the view that organisational development has considerable potential for bringing about effective change, and individual contributions could form a valuable component of personal portfolios. We believe that the existing structures in education and management in the health service are not yet able to support these processes. Evidence from the fields of risk management and quality improvement all point to the need to develop effective organisational systems [4, 28] and the results of this feasibility study indicate that alternative models of sustaining organisational development need careful evaluation.

\section{Acknowledgements}

We owe thanks to the Welsh Office (now the National Assembly for Wales) for funding this project. We also thank the Health Authority coordinators, the facilitators and the practices involved in the project for their unstinting co-operation. Comments were received on drafts of this paper from Jill Paterson, Ann Delahunty, Norma Stockford, Haydn Mayo, Paul Kinnersley, Lionel Jacobson, Steve Rollnick, Rhiannedd Tudor Jones, Sharon Caple.

\section{References}

I. Berwick D: A primer on leading the improvement of systems. BMJ 1996, 31 2:619-22

2. Davies HTO, Nutley SM: Developing learning organisations in the new NHS. BMJ 2000, 320:998-100I

3. Garside P: Organisational context for quality: lessons from the fields of organisational development and change management. Quality in Health Care 1998, 7 Supplements:S8-I 5

4. Moss M, Garside P, Dawson S: Organisational change: the key to quality improvement. Quality in Health Care 1998, 7 Supplement:SI-2

5. Koeck C: Time for organisational development in healthcare organisations. BM] 1998, 317:1267-8

6. Davis DA, Thomson MA, Oxman AD, Haynes RB: Evidence for the effectiveness of CME. A review of $\mathbf{5 0}$ randomized controlled trials. JAMA 1992, 268: IIII-7

7. Davis DA, Thomson MA, Oxman AD, Haynes RB: Changing physician performance. A systematic review of the effect of continuing medical education strategies. JAMA I995, 274:700-5

8. Oxman AD, Thomson MA, Davis DA, Haynes RB: No magic bullets: a systematic review of 102 trials of interventions to help health care professionals deliver services more effectively or efficiently. Can Med Assoc J 1995, I53:1423-31

9. Department of Health: A review of continuing professional development in practice: a report by the Chief Medical Officer. In: Book A review of continuing professional development in practice: $a$ report by the Chief Medical Officer (Editor ed.^eds.). City: DoH; 1998,

10. NHS Executive: Continuing Professional Development: Quality in the new NHS. In: Book Continuing Professional Development: Quality in the new NHS (Editor ed.^eds.). City: Department of Health; 1999,

II. Stanton F, Grant J: The effectiveness of continuing professional development. In: Book The effectiveness of continuing professional development (Editor ed.^eds.). City: Joint Centre for Medical Education, Open University; 1997,

12. Poulton $B C$, West $M$ : The determinants of effectiveness in primary health care teams. Journal of Interprofessional Care 1999, 13:7-18

13. Easterby-Smith M, Burgoyne J, Araujo L: Organizational learning and the learning organization. London: Sage; 1999,

14. Pringle M: Revalidation. BJGP 1999, 49:259-

15. Elwyn G: Professional and practice development plans for primary care. Editorial. BMJ 1998, 3 16:1619-20

16. Parboosingh J: Learning portfolios: potential to assist health professionals with self-directed learning. Journal of Continuing Education in the Health Professions 1996, 16:75-8I

17. Snadden D, Thomas M: The use of portfolio learning in medical education. Medical Teacher 1998, 20:192-9

18. Pitts J, Curtis A, While R, Holloway I: 'Practice Professional Development Plans': general practitioners' perspectives on proposed changes in general practice education. BJGP 1999, 49:959-62

19. Black N: Why we need observational studies to evaluate the effectiveness of health care. BMJ 1996, 3 I 2:1215-8

20. Carlisle S, Elwyn G, Smail SA: Personal and practice development plans in primary care in Wales. Journal of Interprofessional Care 2000, 14:39-48

21. Elwyn G, Smail SA, Carlisle S: Practice and Professional Development Plans in Primary Care: a feasibility study in the five health authorities in Wales: Report to the National Assembly of Wales. In: Book Practice and Professional Development Plans in Primary Care: a feasibility study in the five health authorities in Wales: Report to the National Assembly of Wales (Editor ed.^eds.). City: Department of Postgraduate Education for General Practice in Wales, University of Wales College of Medicine; 1999,

22. Rogers S, Humphrey C, Nazareth I, Lister S, Tomlin Z, Haines A: Designing trials of interventions to change professional practice in primary care: lessons from an exploratory study of two change strategies. $B M J$ 2000, 320:1580-3

23. Crabtree BF, Miller WL: Doing Qualitative Research. London: Sage; 1992, 
24. Elwyn G, Hocking P: Organisational development in general practice: lessons from practice and professional development plans (PPDPs). BMC Family Practice 2000, I:2-

25. Pearson P, Spencer J: Promoting Teamwork in Primary Care: a research based approach. London: Arnold; 1997,

26. Huntington J, Gillam S, Rosen R: Clinical governance in primary care: Organisational development for clinical governance. BMJ 2000, $321: 679-682$

27. Marshall MN: Improving quality in primary care: qualitative case study of barriers faced by health authorities. BMJ 1999 , 319:164-7

28. Garside P: Organisational context for quality: lessons from the fields of organisational development and change management (http://www.bmj.com/misc/qhc/8-15.shtml). Quality in Health Care 1998, 7(Suppl):S8-SI 5

\section{Pre-publication history}

The pre-publication history for this paper can be accessed here:

http://www.biomedcentral.com/content/backmatter/ 1471-2296-2-1-b1.pdf

Publish with BioMedcentral and every scientist can read your work free of charge

"BioMedcentral will be the most significant development for disseminating the results of biomedical research in our lifetime." Paul Nurse, Director-General, Imperial Cancer Research Fund

Publish with BMc and your research papers will be:

- available free of charge to the entire biomedical community

- peer reviewed and published immediately upon acceptance

- cited in PubMed and archived on PubMed Central

- yours - you keep the copyright

Submit your manuscript here:

http://www.biomedcentral.com/manuscript/
BioMedcentral.com 